R. M. Davis

University of California, Davis

P. D. Colyer

Red River Research Station, Louisiana State University Agricultural Center, Bossier City

C. S. Rothrock

University of Arkansas, Fayetteville

J. K. Kochman

Department of Primary Industries and Fisheries, Toowoomba, Queensland, Australia

\title{
Fusarium Wilt of Corton: Population Diversity and Implications for Management
}

Fusarium wilt of cotton, caused by the fungus Fusarium oxysporum Schlechtend. f. sp. vasinfectum (Atk.) Snyd. \& Hans, was first identified in 1892 in cotton growing in sandy acid soils in Alabama (8). Although the disease was soon discovered in other major cotton-producing areas, it did not become global until the end of the next century. After its original discovery, Fusarium wilt of cotton was reported in Egypt (1902) (30), India (1908) (60), Tanzania (1954) (110), California (1959) (33), Sudan (1960) (44), Israel (1970) (27), Brazil (1978) (5), China (1981) (17), and Australia (1993) (56). In addition to a worldwide distribution, Fusarium wilt occurs in all four of the domesticated cottons, Gossypium arboretum L., G. barbadense L., G. herbaceum L., and G. hirsutum L. $(4,30)$.

Disease losses in cotton are highly variable within a country or region. In severely infested fields planted with susceptible cultivars, yield losses can be high. In California, complete crop losses in individual fields have been observed (R. M. Davis, unpublished). Disease loss estimates prepared by the National Cotton Disease Council indicate losses of over 109,000 bales $(227 \mathrm{~kg}$ or $500 \mathrm{lb})$ in the United States in 2004 (12).

\section{Symptoms}

Symptoms of Fusarium wilt can appear at any stage of crop development. The cotyledons of affected seedlings wilt and

Corresponding author: R. M. Davis, Department of Plant Pathology, University of California, Davis 95616; E-mail: rmdavis@ucdavis.edu

DOI: 10.1094/PD-90-0692

(c) 2006 The American Phytopathological Society die rapidly. Symptoms at this stage can be confused with symptoms of damping-off caused by Pythium spp., Rhizoctonia solani Kuhn, and Fusarium spp., but the brown vascular system of the hypocotyl distinguishes Fusarium wilt from seedling disease. The death of seedlings results in uneven stands, which further contribute to production problems throughout the season (Fig. 1). Symptoms in older plants include stunting, wilting, chlorosis and necrosis of leaves, dieback often beginning at the top of the plant, and plant death (Figs. 2 and 3 ). The most diagnostic symptom of Fusarium wilt is the dark brown discoloration of the vascular system (Fig. 4). Some af-

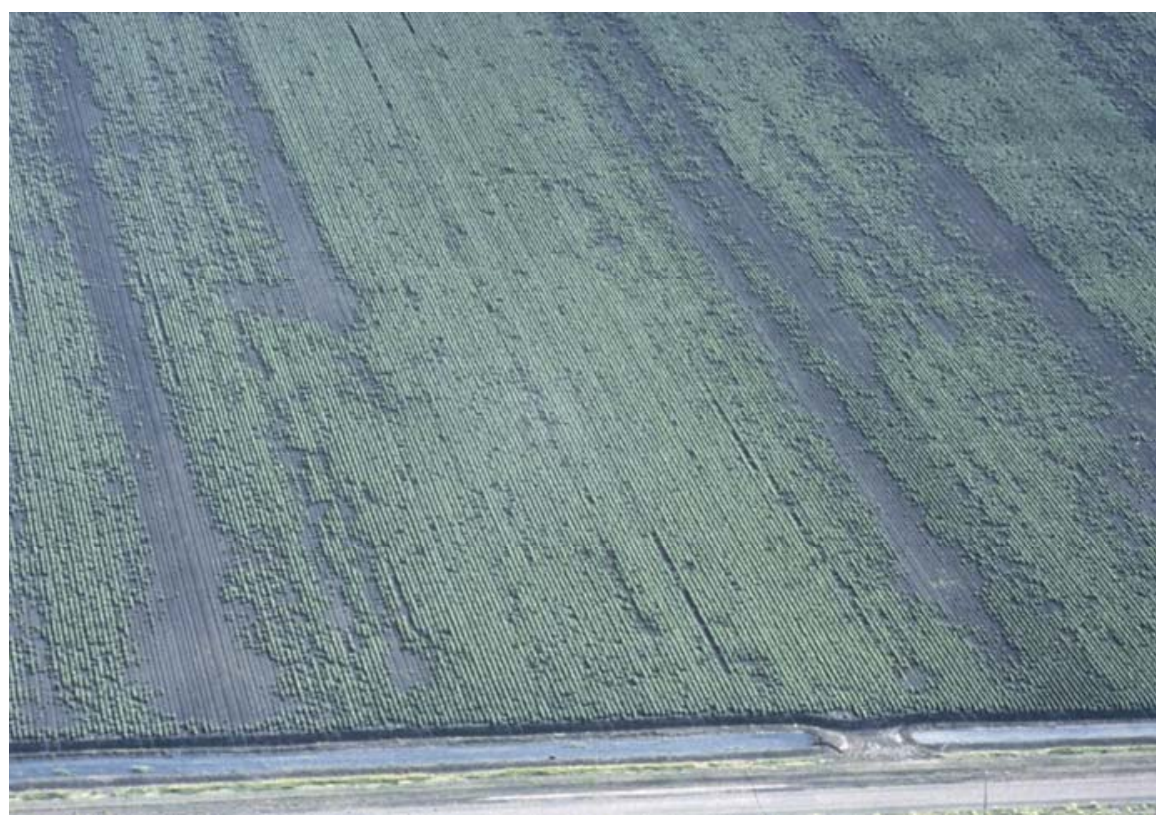

Fig. 1. Aerial view of an Australian cotton field affected by Fusarium wilt. Dissemination of the pathogen in furrow-irrigation water or in soil moved down the rows by farm implements is evident by the distribution of dead plants (gray areas) in the field. 
is rarely seen in nonirrigated cotton crops, but the disease is common in nonirrigated cotton in the mid-south of the United States where annual rainfall is greater $(12,56)$.

Many factors influence the development of Fusarium wilt in a field, including virulence of the population of $F$. oxysporum $\mathrm{f}$. sp. vasinfectum, susceptibility of the cotton cultivar, climatic conditions, soil type, soil fertility, and interactions with nematodes and other soilborne microorganisms. All of these factors may impact the severity of the disease and subsequent yield losses. Visible symptoms may not be apparent when low inoculum densities of the fungus are present. In a greenhouse study, submerging root systems of susceptible cultivars in inoculum of $F$. oxysporum $\mathrm{f}$. sp. vasinfectum did not result in visible aboveground symptoms until spore concentrations in excess of $10^{5}$ conidia per milliliter were used (104). Symptoms in more resistant cotton cultivars were not evident until concentrations of $10^{6}$ conidia per milliliter were used to inoculate plants. Garber et al. (32) found that 77,000 conidia per gram of artificially infested soil was required for symptom expression, but only 650 conidia per gram of soil was required when plants were grown in the presence of the root-knot nematode. Time of infection also determines the extent of yield losses. Plants that are infected early may die before producing any bolls, while plants infected after flowering often survive but produce fewer and smaller bolls. These plants often mature earlier and their bolls open sooner, resulting in poorer quality lint.

\section{Characterization of Races}

$F$. oxysporum includes a large number of pathogenic and saprophytic biotypes that share morphological features. Parasitic biotypes that cause Fusarium wilt of cotton were grouped into the forma specialis $v a$ sinfectum. Several races have been characterized within this forma specialis using both cotton and noncotton differential hosts. Recently, DNA-based techniques have been used to validate these races and to elucidate relationships among them.

In 1927, Fahmy reported the occurrence of three groups of $F$. oxysporum f. sp. vasinfectum populations based on their differential reactions on three species of cotton, American upland ( $G$. hirsutum), Egyptian ( $G$. barbadense), and Indian ( $G$. arboretum and $G$. herbaceum) (30). Armstrong and Armstrong later argued that the use of entire species of Gossypium as a set of differentials was oversimplified because cultivar reactions within a species of cotton were variable (4). They concluded that these distinctive groups of $F$. oxysporum $\mathrm{f}$. sp. vasinfectum (which they called races) could be identified but only if certain cotton cultivars were used as differentials. Armstrong and Armstrong (4) also be- lieved Fahmy used weakly virulent isolates of what was probably race 1 since their experience with race 1 was greatly different. They speculated that Fahmy's isolates lost pathogenicity while in continuous culture. In any case, no race designations could be made by using entire species as differential hosts since not all the cultivars in any one of the Gossypium species exhibited similar symptoms.

While describing symptomatic and asymptomatic hosts of race 1, Armstrong and Armstrong noted that certain isolates caused wilt of field-grown soybean (Glycine $\max (\mathrm{L}$.) Merr.) and flue-cured tobacco (Nicotiana tabacum L.) and confirmed this observation in greenhouse trials (6). The new strain, called race 2 , was formally distinguished from race 1 by its greater virulence on soybean cv. Yelredo and flue-cured tobacco cv. Gold Dollar. In replicated tests, race 2 caused wilt on 40.3 and $70.8 \%$ of inoculated Yelredo soybean and Gold Dollar tobacco plants, respectively, while race 1 caused up to 5.5 and $9.1 \%$ wilt of these crops. Armstrong and

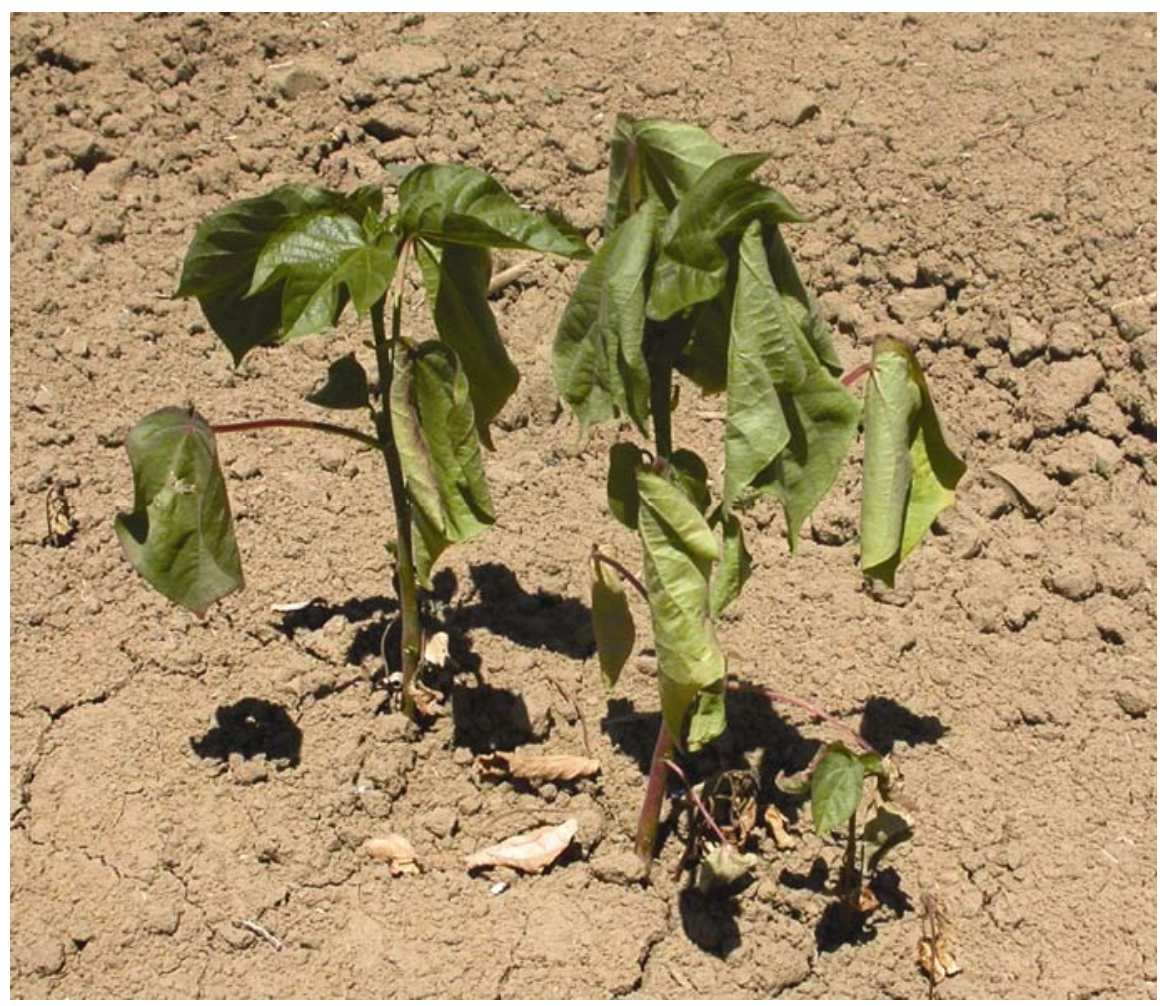

Fig. 2. Wilt of foliage of cotton plants of various ages affected by Fusarium wilt. Older plants as well as seedlings may succumb to the disease.

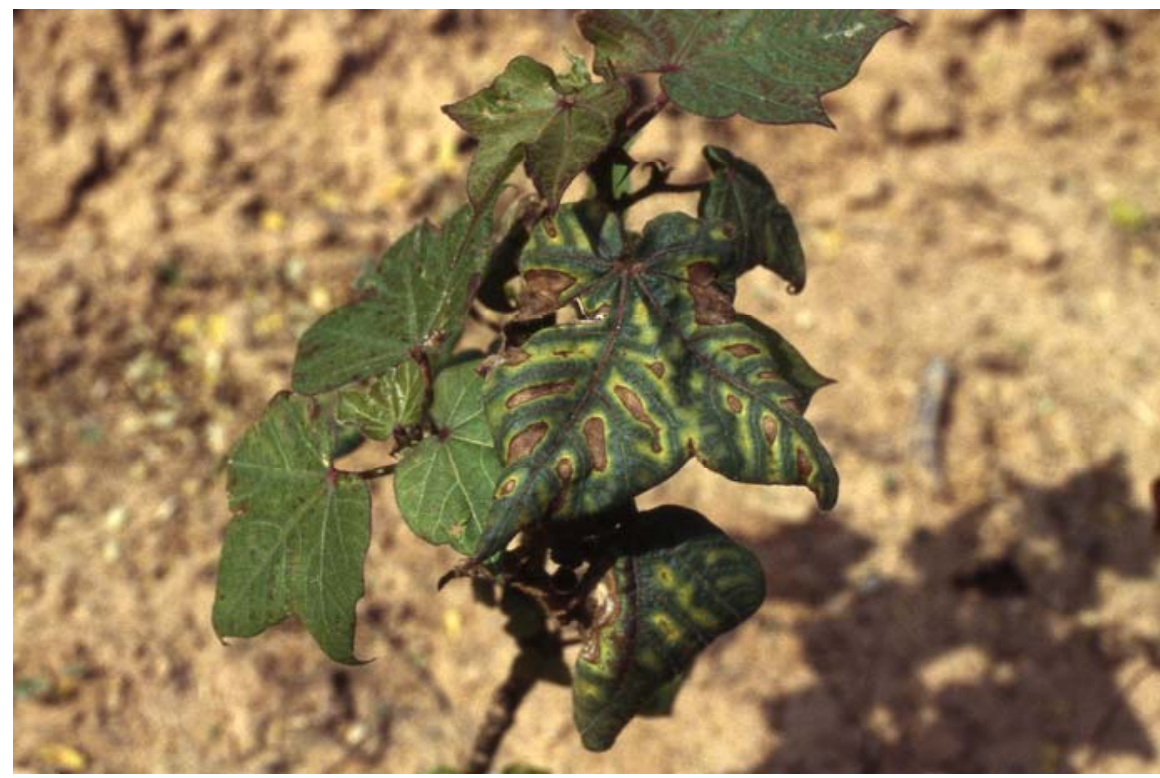

Fig. 3. Fusarium wilt-induced interveinal chlorosis and necrosis of cotton foliage. 
Armstrong concluded that race 2 was a mutant of race 1 with increased virulence on soybean and tobacco. However, the reactions of 29 cultivars and breeding lines of cotton to races 1 and 2 were similar (6).

The observation that races 1 and 2 could not be separated based on their reaction on cotton inevitably led to confusion about race designation since the term "race" implied a genetic relationship between pathogen and host. By using a set of noncotton hosts to define race, Armstrong and Armstrong were not defining race based on a set of differential reactions in one host (i.e., a set of Gossypium plants possessing different genes for resistance to $F$. $o x$ ysporum f. sp. vasinfectum). Armstrong and Armstrong's definition of resistance also was confusing, since they based susceptibility on the reaction in $50 \%$ or more of inoculated plants (4). If more than $50 \%$ of plants of a cultivar developed external symptoms of wilt, it was considered susceptible in their assessment. A cultivar was considered resistant if less than $50 \%$ of inoculated plants developed external symptoms. Therefore, the demarcation between susceptibility and resistance of some cultivars was somewhat arbitrary, especially since a host's reaction was quite variable.

If Armstrong and Armstrong had limited the naming of races according to reactions in cotton, three races that would have been designated were: an American race (a single race containing races 1,2 , and 6 as later delineated by Armstrong and Armstrong), an Egyptian race (later named race 3 ), and an Indian race (later named race 4) (4). These designations could have been based on a unique set of reactions on $G$. arboretum cv. Rozi, G. barbadense cv. Sakel, and G. hirsutum cv. Acala (Table 1). The separation of race 1 from race 2 was

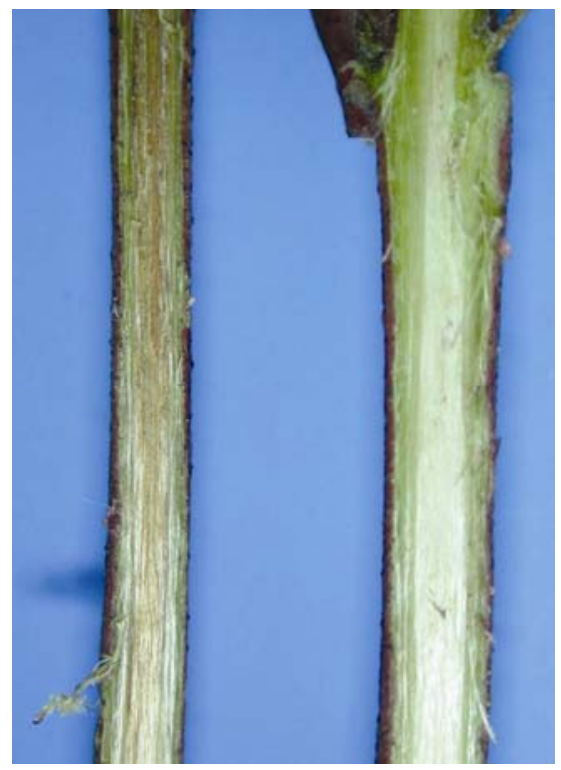

Fig. 4. Characteristic vascular discoloration of a cotton stem infected by Fusarium oxysporum $\mathrm{f}$. sp. vasinfectum (left) and healthy stem (right). clearly desirable to Armstrong and Armstrong, however, since there were clear differences of virulence on tobacco and soybean in the greenhouse and field (4). Unlike the U.S. isolates, neither the Egyptian nor Indian isolates caused wilt of alfalfa (Medicago sativa L.), Yelredo soybean, okra (Hibiscus esculentus L.), Kentucky 5 burley tobacco, or Gold Dollar flue-cured tobacco (Table 2).

Race 5 was described in Sudan in 1966 (44) but was eventually withdrawn after Nirenberg et al. (75) compared cultural characteristics and pathogenicity tests and found that 3 and 5 were identical. Isolates of races 3 and 5 were separated easily from the other races by their smaller conidia, in addition to the development of symptoms on differential hosts.

In 1978, Armstrong and Armstrong described race 6 from Brazil (5). This race caused wilt of $G$. hirsutum and okra, like races 1 and 2, but did not wilt alfalfa, soybean, tobacco, or lupine (Lupinus luteus L.), which are susceptible to race 1 and/or 2. Race 6 could not be distinguished from races 1 or 2 in pathogenicity tests on cotton cultivars. Hence, the designation of some races of $F$. oxysporum f. sp. vasinfectum continued in the absence of a differential set of cotton cultivars.

In 1985, Chen et al. described races 7 and 8 in China based on the reactions of cotton, tobacco, alfalfa, okra, and soybean (Tables 1 and 2) (17). Isolates of races 4 and 7 were separated by their pathogenicity on cotton and noncotton hosts, but later genetic analysis suggested that they may be identical (89). The conflict between the original pathogenicity tests and the subsequent genetic studies remains unresolved.

The latest described population of $F$. oxysporum f. sp. vasinfectum is a new bio- type (actually two closely related biotypes) discovered in Australian cotton crops in 1993 (23). No race designation was made for these strains since by this time the term "race" as used for $F$. oxysporum f. sp. vasinfectum was deemed invalid (23). The Australian biotypes caused wilt in G. hirsutum cv. Siokra 1-4 and cv. Acala 44, G. barbadense cvs. Ashmouni and Sakel, but did not cause wilt in $G$. arboretum cv. Roseum. The reactions of Australian isolates on this set of cotton differentials are identical to those expected by race 1 . However, unlike race 1 or 2, the Australian isolates did not affect tobacco, lupine, or soybean (23), which is similar to the reaction expected by race 6 . Later genetic analyses indicated that Australian isolates are clearly distinct from race 1,2 , or 6 isolates from the Americas (54). Cultures of Australian isolates produced strong and distinctive volatile aroma as do some, but not all, California isolates of race 1 (94).

By the 1990s, DNA-based techniques were employed in conjunction with pathogenicity tests to distinguish the various races of $F$. oxysporum f. sp. vasinfectum. Such tests were needed when differential cotton hosts were not available or strict quarantine issues did not allow field or greenhouse pathogenicity tests with foreign isolates. In 1993, Bridge et al. (13) assessed vegetative compatibility groups (VCG), restriction fragment length polymorphism (RFLP), and aesculin hydrolysis among races $1,2,3$, and 4 . Because isolates with the same allele at each of the loci that govern vegetative compatibility were genetically similar, this was a useful tool to examine relationships. Races 1 and 2 belonged to the same VCG and race 3 belonged to another. (Race 4 was not included in this part of their study.) Races 1

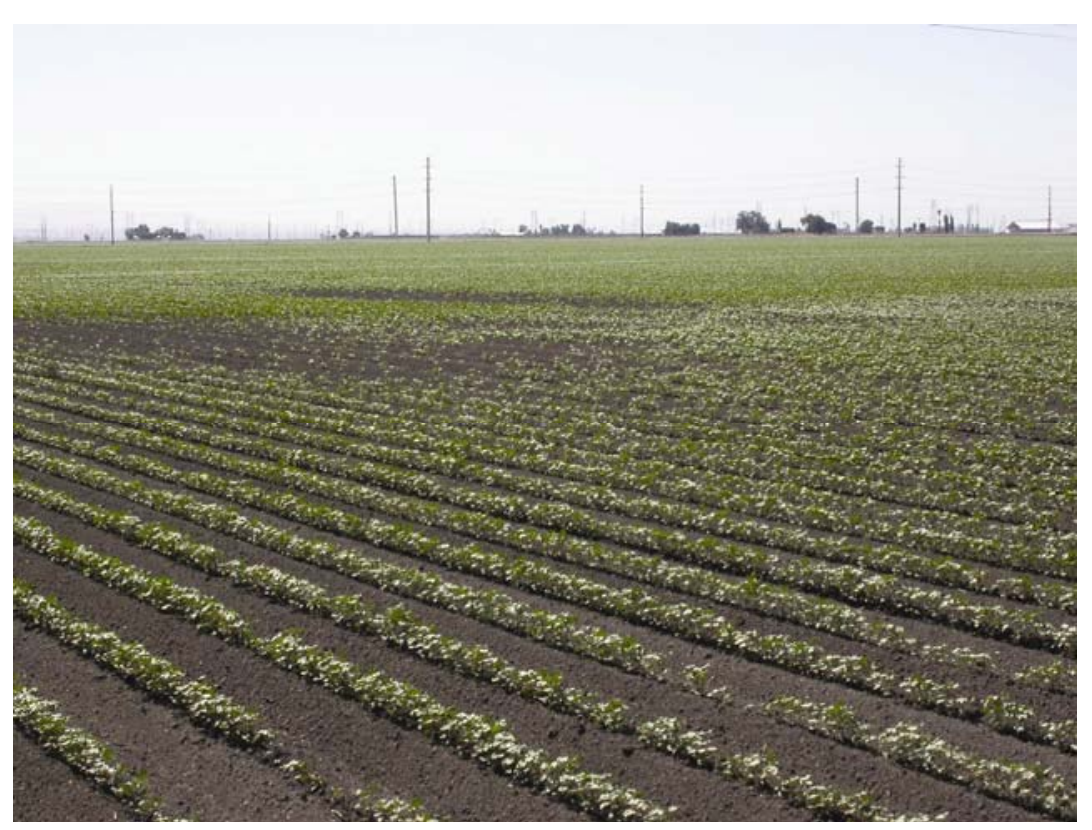

Fig. 5. Disease foci of dead and missing plants in a field infested by Fusarium oxysporum f. sp. vasinfectum. 
and 2 shared one RFLP pattern, and race 3 and 4 each had a unique RFLP pattern. Races 1 and 2 could, however, be separated on the basis of aesculin hydrolysis. In that test, aesculin was incorporated into an agar medium, and the production of aesculetin was indicated by its reaction with an iron salt to give a dark brown/black color in the medium (13). Race 1 did not significantly discolor the medium (a negative reaction in the aesculin hydrolysis test), while races 2,3 , and 4 all produced significant blackening. Therefore, the general conclusions were that races 1 and 2 were similar but could be distinguished in the aesculin assay, and races 3 and 4 were each unique. The unique reaction of race 2 in the aesculin assay was also noted by Rutherford et al. (82).

Assigbetse et al. (7) determined races based on the susceptibility of cotton cultivars Isa 205 and Acala S.J. (G. hirsutum), Ashmouni 106 and Sakel (G. barbadense), and CG17 (G. arboretum). Races 1, 2, and 6 caused wilt of both $G$. hirsutum cultivars and both $G$. barbadense cultivars, but not $G$. arboretum; race 3 caused wilt of Sakel (G. barbadense) and CG17 (G. arboretum) but not the others; and race 4 caused wilt of CG17 (G. arboretum) only (Table 1). In their tests using these differentials, plants were either asymptomatic or symptomatic, indicating distinct resistance genes. They concluded that races 1,2 , and 6 belonged in a single group (called race A for convenience) based on these differentials and evidence of similarity by RAPD analysis (although race 6 had distinct RAPD patterns). Lumping races 1,2 , and 6 into a single group did not contradict Armstrong and Armstrong, who found all three of these races had similar reactions in cotton (5).

Fernandez et al. (31) established 10 VCGs (0111-01110) among F. oxysporum f. sp. vasinfectum isolates and concluded that each was an independently evolving lineage. Within group A (races 1, 2, and 6 collectively), there were eight VCGs (0111, 0112, and 0115-01110). Races 3 and 4 were placed into VCGs 0113 and 0114 , respectively. In this designation, the first three digits identify the forma specialis (011 for $F$. oxysporum f. sp. vasinfectum) and the last digit or digits identify the subgroup. In contrast to Bridge et al. (13), Fernandez et al. found a unique VCG for each race included in their study (races 1 , 2, 3, 4, and 6). Most isolates within the same VCG had the same rDNA and mtDNA haplotypes, but three distinct mtDNA haplotypes occurred in VCG0114. Based on all evidence, race 3 isolates represented a clone. In Israel, all race 3 isolates also belonged to a single VCG (52). Race A had three rDNA and four mtDNA haplotypes, in addition to the eight VCGs. VCGs of Australian strains were unique and later designated 01111 and 01112 (23). The Australian strains also produced a color change in the aesculin hydrolysis test.

According to patterns of cellular fatty acid profiles, another means to characterize isolates, race 1 belonged to one subgroup with races 2 and 6 in another subgroup (all three in group A), race 4 was in group $\mathrm{B}$, and race 3 belonged to group $\mathrm{C}$ (38). This was further evidence that among these isolates, there were three groups, one that contained races 1,2 , and 6 , and one each for race 3 and race 4 .

Partial sequences of translational elongation factor $(\mathrm{EF}-1 \alpha)$, nitrate reductase, phosphate permase, and the mitochondrial small subunit rDNA genes were sequenced by Skovgaard et al. in 2001 (89). Isolates of $F$. oxysporum f. sp. vasinfectum were polyphyletic with at least two independent evolutionary origins. Lineage I contained race 3 , an independent clade, lineage II contained races 1,2 , and 6 , lineage III contained race 8 , and lineage IV contained race 4. Kim et al. (54) included the Australian biotypes in their study on multigene genealogies of $F$. oxysporum f. sp. vasinfectum. Isolates were characterized by partial sequences of translational elongation factor $(\mathrm{EF}-1 \alpha)$, phosphate permase, and beta-tubulin genes, restriction digests of the intergenic spacer (IGS) region of nuclear rDNA, and pathogenicity tests. The Australian isolates formed a strongly supported independent clade for a total of three independent evolutionary origins of F. oxysporum $\mathrm{f}$. sp. vasinfectum (race 3 , the Australian biotypes, and all the rest) (Fig. 6). There was a total of nine haplotypes based on restriction digests of the IGS region. Race 6 , represented by a single isolate from the American Type Culture Collection, possessed its own unique rDNA IGS haplotype. Except for a single isolate included in the study, races 1 and 2 shared the same restriction pattern. Kim et al. (54) also demonstrated that there is no longer a strict worldwide geographical division among genotypes of $F$. oxysporum f. sp. vasinfectum. In California alone, representatives of four groups were noted: races $1,3,4$, and 8 . Today, race 1 is common in the Americas and much of Africa (for example, Ivory Coast, Tanzania, and Zimbabwe), race 3 is common in Egypt, Sudan, and Israel, race 4 in India, Uzbekistan, and China, races 7 and 8 in China, and the Australian biotypes are limited to that country. As researchers continue to use genetic tools to characterize more isolates, the distribution of various biotypes will no doubt be more widely distributed than previously assumed.

Although Armstrong and Armstrong (46) formally delineated races for $F$. oxysporum f. sp. vasinfectum based on differences in the reaction of cultivars of host plants, including plants of different species (or even plants of different families), race

Table 1. Reactions of cotton hosts for differentiating races of Fusarium oxysporum f. sp. vasinfectum ${ }^{\mathrm{a}}$

\begin{tabular}{llllllllc}
\hline & \multicolumn{10}{c}{ Race } \\
\cline { 2 - 9 } Host (Gossypium sp.) & $\mathbf{1}$ & $\mathbf{2}$ & $\mathbf{3}$ & $\mathbf{4}$ & $\mathbf{6}$ & $\mathbf{7}$ & $\mathbf{8}$ & Australian biotypes \\
\hline G. hirsutum cv. Acala & $\mathrm{S}$ & $\mathrm{S}$ & $\mathrm{R}$ & $\mathrm{R}$ & $\mathrm{S}$ & $\mathrm{S}$ & $\mathrm{I}$ & $\mathrm{S}$ \\
G. barbadense cv. Sakel & $\mathrm{S}$ & $\mathrm{S}$ & $\mathrm{S}$ & $\mathrm{R}$ & $\mathrm{S}$ & $\mathrm{S}$ & $\mathrm{I}$ & $\mathrm{S}$ \\
G. arboretum cv. Rozi & $\mathrm{R}$ & $\mathrm{R}$ & $\mathrm{S}$ & $\mathrm{S}$ & $\mathrm{R}$ & $\mathrm{S}$ & $\mathrm{I}$ & $\mathrm{R}$ \\
\hline
\end{tabular}

${ }^{a}$ See references $4,7,17$, and 23. In some studies, certain cultivars were substituted for the ones shown. $\mathrm{S}=$ susceptible (wilt symptoms), $\mathrm{R}=$ resistant (no wilt symptoms), and I = intermediate (some plants susceptible).

Table 2. Reactions of noncotton hosts for differentiating some races of Fusarium oxysporum f. sp. vasinfectum ${ }^{\mathrm{a}}$

\begin{tabular}{lllllllcc}
\hline & \multicolumn{1}{c}{ Race } \\
\cline { 2 - 9 } Host & $\mathbf{1}$ & $\mathbf{2}$ & $\mathbf{3}$ & $\mathbf{4}$ & $\mathbf{6}$ & $\mathbf{7}$ & $\mathbf{8}$ & Australian biotypes \\
\hline Medicago sativa cv. Grimm & $\mathrm{S}$ & $\mathrm{S}$ & $\mathrm{R}$ & $\mathrm{R}$ & $\mathrm{R}$ & $\mathrm{I}$ & $\mathrm{S}$ & $?$ \\
Nicotiana tabacum cv. Gold Dollar & $\mathrm{R}$ & $\mathrm{S}$ & $\mathrm{R}$ & $\mathrm{R}$ & $\mathrm{R}$ & $\mathrm{R}$ & $\mathrm{I}$ & $\mathrm{R}$ \\
Glycine max cv. Yelredo & $\mathrm{R}$ & $\mathrm{S}$ & $\mathrm{R}$ & $\mathrm{R}$ & $\mathrm{R}$ & $\mathrm{I}$ & $\mathrm{I}$ & $\mathrm{R}$ \\
\hline
\end{tabular}

a See references 4, 17, and 23. $\mathrm{S}=$ susceptible (wilt symptoms), $\mathrm{R}=$ resistant (no wilt symptoms), and $\mathrm{I}=$ intermediate (some plants susceptible). 
designations should be revisited. Because races 1,2 , and 6 are not distinguishable by their pathogenicity on cotton, but only on secondary host plants, they should be combined into a single group (the name race $\mathrm{A}$ has been proposed [7]). In any case, the differential reactions on noncotton hosts have no relevance to cotton. A set of differentials among Gossypium cultivars should be standardized despite the fact the genotypes of races 1,2 , and 6 can be distinguished by one or more of the genetic analyses outlined above.

\section{Host Range}

Although it is widely accepted that wiltinducing strains of $F$. oxysporum infect root epidermal and cortical cells of many plants without causing disease, some strains of $F$. oxysporum f. sp. vasinfectum cause measurable wilt in diverse hosts $(3,4,6,96)$. Armstrong and Armstrong (4) noted wilt of field-grown soybean cv. Yelredo and flue-cured tobacco cv. Gold Dollar by some isolates of $F$. oxysporum $\mathrm{f}$. sp. vasinfectum. In greenhouse pathogenicity tests, some strains caused wilt of alfalfa, burley tobacco, chili pepper (Capsicum sp.), Chinese lantern (Physalis alkekengi L.), cowpea (Vigna unguiculata (L.) Walp.), green gram (Vigna radiate (L.) Wilczek), hollyhock (Alcea rosea L.), lupine, and okra $(4,37,95)$. Apparently, $F$. oxysporum f. sp. vasinfectum has a much wider host range than generally allowed in the $F$. oxysporum-forma speciales system. Plants known to harbor $F$. oxysporum $\mathrm{f}$. sp. vasinfectum without exhibiting any aboveground symptoms include finger millet (Eleusine coracana (L.) Gaertn.), pearl millet (Pennisetum glaucum (L.) R. Br.), snapdragons (Antirrhinum majus L.), sorghum (Sorghum bicolor (L.) Moench), and sweet potato (Ipomoea batatas (L.) Lam.),

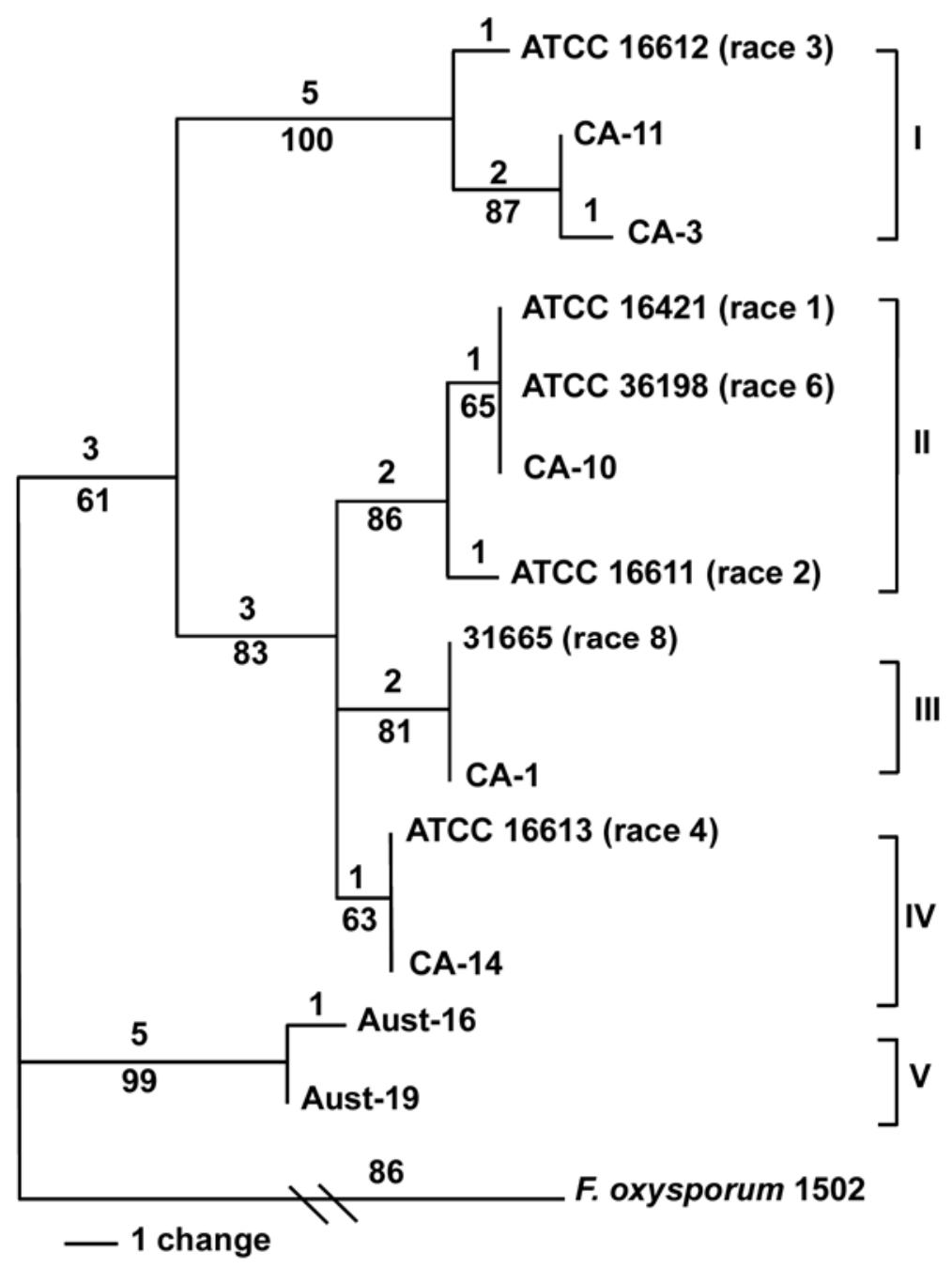

Fig. 6. Single most parsimonious tree generated from combined analysis of translational elongation factor, beta tubulin, and phosphate permase gene sequences of isolates of Fusarium oxysporum $\mathrm{f}$. sp. vasinfectum representing all know biotypes $(\mathrm{Cl}=$ $0.9640, \mathrm{RI}=0.9216$ ). The outgroup is a saprophytic Fusarium oxysporum (isolate 1502). Five lineages (I to $\mathrm{V}$ ) of $F$. oxysporum $\mathrm{f}$. sp. vasinfectum races are identified by brackets. Three independent origins of $F$. oxysporum f. sp. vasinfectum are apparent: race 3, the Australian biotypes, and all the rest. Numbers of changes are noted above branches. Bootstrap frequencies from 1,000 replications are noted below branches. See reference 54 for a complete description. among others $(3,16)$. Several weed hosts in the Malvaceae, Sterculiaceae, and Tiliaceae were susceptible to infection following artificial inoculation (110). Some produced symptoms, but many acted as symptomless carriers. Clearly, F. oxysporum $\mathrm{f}$. sp. vasinfectum is able to multiply on the roots of a number of crop and weed species. Although the fungus occasionally moves into the xylem of the nonwilt-susceptible hosts, most of the invasion is spatially limited to root cortical cells. In a California study on populations of $F$. oxysporum f. sp. vasinfectum in soil, natural infections of $F$. oxysporum f. sp. vasinfectum occurred in the roots of barley (Hordeum vulgare L.), cheeseweed (Malva parviflora L.), and yellow nutsedge (Cyperus esculentus L.) (96). Based on populations of $F$. oxysporum $\mathrm{f}$. sp. vasinfectum in soil over a 5-year period, the pathogen multiplied more rapidly on these secondary hosts in some fields than on cotton. $F$. oxysporum f. sp. vasinfectum apparently invaded the root tissue of these secondary hosts when they were in a senescent stage of development. For example, the fungus was readily recoverable from the dried roots of barley crop residue. In another study, the incidence of Fusarium wilt of cotton in a field after an absence of cotton for 12 years was still high (3). It was concluded that crop rotation schemes must take into account the ability of $F$. oxysporum f. sp. vasinfectum to persist and multiply on other hosts, including a variety of weeds. Furthermore, F. oxysporum f. sp. vasinfectum can be isolated from stems of resistant varieties of cotton without external or internal symptoms $(3,15)$.

\section{Seed Transmission}

The seedborne nature of Fusarium wilt of cotton was first described by Elliott in 1923 (29), when he found that $6 \%$ of the seed in one seed lot from severely wilted plants carried internal infections (inside the seed coat) of F. oxysporum f. sp. vasinfectum. To determine how long the fungus remained viable within seed, he sampled monthly from this seed lot. Within 3 months of the date of collecting the seed, the fungus was recovered 39 times from 769 seeds $(5 \%)$. From the fourth to the seventh month, the fungus was recovered only 7 times from 700 seeds (a reduction from $6 \%$ in the first month to $0.5 \%$ in the sixth and seventh months). However, low survival in seed can still result in transmission to the field since well over 100,000 cotton seeds are typically planted per hectare. In one study, only $5 \%$ of the plants grown from artificially infested seed (80 to $100 \%$ infestation) yielded Fusarium wilt in the first year, demonstrating that several years might elapse after its introduction before disease would become noticeable (29).

Most infected seed originates from plants that develop symptoms late in the 
season, because they are more likely to survive to maturity than plants infected before flowering (39). Infection levels in seed from plants colonized late in the growing season ranged from $2 \%$ in a resistant cultivar to $21 \%$ in a susceptible cultivar. Most of the infected seed came from plants showing wilt symptoms at harvest, although there was some infected seed from symptomless plants of all the cultivars, including resistant cultivars. Some plants were infected late and never showed symptoms.

Apparently, F. oxysporum f. sp. vasinfectum usually enters through penetrations of the seed coats in infested bolls rather than systemically through vascular connections. Fallen flowers, bolls, and squares are important in the production of spores of $F$. oxysporum, which then initiate boll rots (97). The ease of distribution of spores and their ability to germinate and grow in bolls and seed appear to be important in determining eventual seed infections. Contamination of seed with trash, dust, or soil may also be responsible for transporting the pathogen long distances. The seedborne nature of this pathogen is no doubt responsible for the worldwide distribution of some strains and is an important consideration in the movement of seed from one area to another.

\section{Survival in Soil}

Once a field is infested with $F$. $o x$ ysporum f. sp. vasinfectum, the fungus usually persists indefinitely $(96,110)$. Survival of the fungus in soils not planted to cotton for over 10 years has been documented (94). Because of this ability, it can be classified as a true soil inhabitant (34).

Long-term survival of $F$. oxysporum $\mathrm{f}$. sp. vasinfectum in soil, like most formae speciales of the fungus, is probably in the form of chlamydospores in decaying plant tissue $(35,72)$. Chlamydospores are under fungistasis and remain dormant in the soil until fresh organic matter or exudates and leachates from plant roots stimulate their germination (63). The germinated chlamydospores produce hyphae that eventually form conidia and new chlamydospores if a suitable host is not found. Organic matter and exudates and leachates from roots required to stimulate the germination of chlamydospores and subsequent colonization are not limited to cotton. The ability of $F$. oxysporum f. sp. vasinfectum to colonize the roots of plants other than cotton is significant for its long-term survival since hyphae, conidia, and chlamydospores may be destroyed by soil microorganisms (101). Regardless of the mode of survival, the ability of the pathogen to survive in soils for long periods has important consequences on disease management.

\section{Detection in Soil and Seed}

Various techniques have been used to detect the presence of $F$. oxysporum. Stan- dard disinfestation methods and nonselective media are sufficient for isolating the pathogen from plant material. Kappelman (50) used water agar for isolating from cotton stems in a survey of Fusarium wilt in the United States, and Baird and Carling (9) plated cotton residue on potato dextrose agar. Colonies on potato dextrose agar are white and grow quickly (about 1 $\mathrm{cm}$ per day at $25^{\circ} \mathrm{C}$ ). Various shades of violet are produced in the agar. The use of selective media such as peptone-PCNB agar (Nash-Snyder medium) has greatly improved the ability to detect $F$. oxysporum and other Fusarium spp. in soil and plant debris $(14,62,73,83,109)$. Hillocks (39) used peptone-PCNB agar to assess seed infection and relate isolation frequency to cultivar resistance and plant symptoms. By comparing colonies of $F$. oxysporum $\mathrm{f}$. sp. vasinfectum on this medium to colonies from soil dilutions, Smith and Snyder (96) were able to quantify colony forming units of the fungus in cotton fields. Other selective media include modified Czapek-Dox medium for isolating Fusarium spp. from plants and residue and Komada's medium for isolating $F$. oxysporum from plant tissue or soil $(14,73,109)$. Colonies on these media have a more typical appearance and pigmentation (relative to potato dextrose agar) than they do on peptone-PCNB medium. Peptone-PCNB medium has been used more frequently in studies on $F$. oxysporum $\mathrm{f}$. sp. vasinfectum than these other selective media.

Immunological and DNA-based assays, primarily based on PCR, have been developed for Fusarium spp. These have been summarized by Nicholson (74) and are primarily used for the detection and identification of Fusarium spp. in plant tissue. Kumar et al. (61) produced a polyclonal antibody useful in the detection of $F$. oxysporum f. sp. vasinfectum in $G$. arboretum and in soil suspensions transferred to Richard's medium. Moricca et al. (69) developed primers from the ITS region of F. oxysporum f. sp. vasinfectum to identify the pathogen in cotton plants. The primers did not amplify other fungi associated with cotton.

Because the identity of $F$. oxysporum $\mathrm{f}$. sp. vasinfectum is based on its ability to cause disease of cotton, pathogenicity assays must be conducted for confirmation. In the future, molecular techniques and vegetative compatibility assays may allow pathogenicity tests to be bypassed, but these methods are not yet reliable for identification of the pathogen, especially given current limited knowledge of saprophytic isolates of $F$. oxysporum associated with cotton. In addition, independent origins of $F$. oxysporum f. sp. vasinfectum in different areas of the world suggest closer relationships to endemic populations of $F$. oxysporum than to populations of $F$. oxysporum f. sp. vasinfectum in other cotton growing regions.

\section{Interactions with Nematodes}

Although Fusarium wilt alone is a serious disease of cotton, disease incidence and severity is often greater in the presence of nematodes. The interaction between root-knot nematode (Meloidogyne incognita (Kofoid \& White) Chitwood) and Fusarium wilt in cotton is one of the first reports of an interaction between a nematode and a fungus (8), and is now one of the most recognized disease complexes in the world. In addition to the root-knot nematode, the reniform (Rotylenchulus reniformis Linford \& Oliveira) (46,70), sting (Belonolaimus gracilis Steiner and $B$. longicaudatus Rau) (21,42,67), lance (Hoplolaimus seinhorsti Luc) (78), and lesion (Pratylenchus brachyurus (Godfrey) Filipjev \& Schuurmans-Stekhoven) (65) nematodes have been implicated in increasing the severity of Fusarium wilt of cotton.

The involvement of nematodes in Fusarium wilt was originally demonstrated by a reduction in the incidence of wilt associated with soil fumigation to control nematodes. The application of carbon disulfide for control of root-knot and meadow nematodes reduced wilt in North Carolina cotton fields (103), and the application of ethylene dibromide reduced wilt in Georgia (91). Wilt was reduced in California through the application of various fumigants $(43,47)$.

Subsequently, the role of nematodes in the development of wilt in cotton was verified through studies using sterilized soil amended with one or both of the pathogens. The classic treatments in these studies included amending the soil with (i) nothing, (ii) Fusarium alone, (iii) nematode alone, or (iv) both pathogens. Using this approach, Martin et al. (64) demonstrated the involvement of root-knot nematodes in increasing wilt in both resistant and susceptible cotton cultivars, but species of Trichodorus, Tylenchorhynchus, and Heliocotylenchus did not increase wilt. Reniform nematodes increased wilt in wilt-susceptible cultivars, but not in wiltresistant cultivars (46). Similarly, lesion nematodes (Pratylenchus brachyurus) increased wilt in the wilt-susceptible cultivar DPL Smoothleaf, but not in the wiltresistant cultivar Auburn 56 (65). The failure to increase wilt in the resistant cultivar, however, may have been related to low populations of the nematode. Soil amended with both $F$. oxysporum f. sp. vasinfectum and sting nematodes resulted in increased wilt in cotton cultivars that were resistant and susceptible to Fusarium wilt (42).

Starr et al. (98) and DeVay et al. (26) demonstrated that the nature of the interaction between $M$. incognita and the wilt pathogen is influenced by the population levels of the pathogens. In addition to pathogen populations, other factors, including environment, sequence of inoculation, and host resistance to both pathogens, influence the nature of the interaction (63). 
Although Atkinson (8) observed that wilt was more severe in the presence of the nematodes over 100 years ago, the exact nature of the interaction is still not clearly understood. One hypothesis is that the nematode vectors fungal propagules to the root and inoculates plants during feeding. This idea does not seem plausible, however, because the stylet of the nematode is too small for the spores to enter. The nematode may passively carry the spores on its cuticle, but this has not been documented (63).

Entry points for the fungus created by nematode feeding was another hypothesis regarding the role of nematodes in the disease complex. Minton and Minton (67) observed that seedling emergence was not reduced in soils simultaneously infested with $F$. oxysporum f. sp. vasinfectum and Meloidogyne incognita or Belonolaimus longicaudatus, but wilt of older seedlings was severe when the wilt pathogen and either nematode were present in the soil. They concluded that $F$. oxysporum f. sp. vasinfectum was a weak pathogen that needed injury caused by nematode feeding before the fungus could induce wilt. Wilt was increased in plants inoculated with $F$. oxysporum f. sp. vasinfectum and sting nematodes at the same time, but wilt was not increased when inoculation with the fungus was delayed by 2 weeks, which suggested the interaction may be mechanical in nature (65). Although the incidence of wilt of both wilt-susceptible and wiltresistant cotton cultivars was increased by sting nematodes, Holdeman and Graham (42) concluded that the relationship was likely more complex than simply providing an entry for the fungus since not all nematodes increased wilt (64).

Subsequent studies provided additional data to support the idea that the interaction was more complex than merely providing entry for the fungus. Wilt was more severe in plants inoculated with $M$. incognita 2 to 4 weeks prior to inoculation with the fungus (77). If wounding were the most significant factor in the interaction, then wilt would be expected to be more severe at the time the nematodes began feeding. It was also shown that mechanical injury to cotton and other crops increased severity of Fusarium wilt less than $M$. incognita injury (63). In stem layering studies, the factors responsible for predisposing plants to Fusarium infection were translocatable (106). Based on anatomical studies, $F$. oxysporum f. sp. vasinfectum colonization of wounds caused by $M$. incognita feeding was not increased (76). Katsantonis et al. (53) demonstrated that $M$. incognita increased Fusarium wilt symptoms even when $F$. oxysporum f. sp. vasinfectum was inoculated into the stems of cotton, physically separating the two pathogens. These studies suggested that the enhancement of susceptibility to $F$. oxysporum f. sp. vasinfectum due to nematodes was most likely related to biochemical and physiological changes induced by nematode parasitism. Although the exact nature of the effect of nematodes on Fusarium wilt has not been clearly determined (63), the mechanism for each interaction may be unique for each parasitic nematode involved in the disease complex (77).

\section{Disease Management}

Management of Fusarium wilt in cotton is difficult. Although host resistance is available, there are no immune cultivars. Chemical management is limited and expensive, and crop rotation is not effective because of the ability of $F$. oxysporum $\mathrm{f}$. sp. vasinfectum to survive in soil for long periods. Since wilt is often associated with the root-knot nematode, resistance, chemi$\mathrm{cal}$, and rotation practices directed at management of the nematode have sometimes proven effective in reducing the incidence and severity of Fusarium wilt.

Host resistance. The use of host resistance to manage Fusarium wilt has been moderately successful. Although there are no wilt-immune cultivars, commercial cultivars with moderate to high levels of wilt resistance have been developed. In the United States, the first wilt-resistant cultivars were produced by mass selection of plants growing in heavily infested fields (92). Upland cotton cultivars with increased resistance to wilt were subsequently produced, but their yield and fiber quality were lower than the then available wilt-susceptible cultivars (28). Kappelman (49) evaluated breeding stock and cultivars from 1969 to 1978 and determined that progress had been made in combining desirable agronomic properties with wilt resistance. The most significant improvements to wilt resistance occurred after 1975. Shepherd and Kappelman (88) evaluated 18 cultivars and breeding lines for wilt resistance in 1986, and noted that lines developed after 1965 had higher resistance than cultivars developed prior to 1965, although none had high levels of resistance. Sicot F1, a cultivar with significantly improved resistance to strains of $F$. oxysporum f. sp. vasinfectum in Australia, was released in 2004 (79).

Hillocks reported that wilt resistance is more complete in Egyptian (G. barbadense) cottons than in Upland (G. hirsutum) cottons (40). Smith and Dick (93) concluded that resistance in Upland cotton was controlled by a major dominant gene with minor modifying genes, and resistance in Egyptian cotton was controlled by two dominant genes. Kappelman (48) showed that resistance in Upland cotton was quantitatively inherited and controlled by several major genes with minor modifying genes. Similar results have been reported in Australia (79). Breeding for resistance to $F$. oxysporum $\mathrm{f}$. sp. vasinfectum has been successful in managing the disease in Egypt, Tanzania, and China (40).
Because nematodes can increase the incidence of Fusarium wilt in cultivars that are both resistant and susceptible to the disease $(40,63)$, planting cotton cultivars with resistance to the nematode is often a sound management practice. High levels of resistance to $M$. incognita reduced wilt severity more effectively than tolerance to wilt or moderate resistance to the nematode $(43,86)$. Unfortunately, only moderate resistance to the root-knot nematode is available and in only a limited number of commercial cultivars.

Progress in the development of cotton cultivars that combine high levels of nematode resistance with agronomically favorable traits has been disappointing. Starr and Smith (99) evaluated cultivars from the last 40 years and determined that wilt resistance had improved, but nematode resistance was less than adequate. Only three commercial cultivars, Stoneville LA 887, Paymaster 1560, and Acala NemX, had acceptable levels of resistance to the root-knot nematode $(18,58,81)$. Stoneville LA 887 and Paymaster 1560 were developed in Louisiana and were well adapted to growing conditions in the mid-south. Unfortunately, seed of neither of these cultivars is available for production. Acala NemX was developed in California but is not adapted to the mid-south and southeastern U.S. production areas.

The development of cultivars with resistance to both Fusarium wilt and root-knot nematode has been difficult. Smith (90) determined that lines often selected for wilt resistance in the Coastal Plain soils in the United States also had nematode resistance, but lines developed on Delta soils of Mississippi and Louisiana did not display nematode resistance. This discrepancy was due to the fact that Coastal Plain soils were heavily infested with the root-knot nematode, but the Delta soils were not. Since nematode resistance was variable among wilt resistant cultivars, it was concluded that the selection for nematode resistance was coincidental. Shepherd (85) suggested that wilt resistance could be developed by breeding for high levels of nematode resistance. Later, he acknowledged that resistance to wilt could be accomplished independently from the nematode, but stated that this approach might only provide moderate field resistance (87). In contrast, Hillocks (40) advised that breeding for wilt resistance could make a significant impact on disease control even though nematodes increased wilt severity of both resistant and susceptible cultivars.

It has been suggested that the indirect selection for nematode resistance could be based on wilt symptoms (51), but Starr and Veech (100) cautioned that indirect selection for nematode resistance might be inadequate in some cultivars because the interaction between the root-knot nematode and wilt may be cultivar specific. Because resistance also may be specific to 
different populations of $F$. oxysporum $\mathrm{f}$. sp. vasinfectum, all cultivars and breeding lines ultimately should be evaluated for resistance to each biotype. In areas where nematodes are not associated with Fusarium wilt, the development of resistance may be the only effective long-term management strategy.

Chemical management. Chemical options to manage Fusarium wilt are limited. Seed treatments that eliminate $F$. oxysporum f. sp. vasinfectum from seed have been reported from China, India (40), and Australia (1). These treatments will likely be ineffective in fields already infested with the pathogen, but may be important in limiting the spread of the pathogen on seed to new areas.

Fusarium wilt can be controlled with soil fumigation with methyl bromide (40), but fumigation is expensive and not economical for a crop like cotton which is planted over large areas. Although fumigation to manage nematodes does reduce Fusarium wilt $(43,47,91)$, there are currently only two fumigants labeled for use in cotton, 1,3-dichloropropene and metamsodium. Fumigation has generally been regarded as too expensive to provide an economic return, but recent data indicate that fumigation with 1,3-dichloropropene to reduce infection of $M$. incognita can provide an economic return in some situations (108)

The ability of aldicarb, a contact nematicide applied in the furrow at planting, to reduce nematode populations and root galling has been widely demonstrated (59), but information on its effect on Fusarium wilt is limited. The effect of aldicarb (Temik 15G) on severity of the disease complex in eight cotton cultivars with different levels of resistance to the disease complex was tested in 1994 and 1995 (19). Across all cultivars, the application of aldicarb reduced root galling and stem discoloration. These differences resulted in increased seed cotton yield and lint percentage.

Cultural practices. Crop rotation is often recommended to reduce the incidence of Fusarium wilt, but the ability of the fungus to survive in the soil for long periods in the absence of cotton limits the effectiveness of rotations $(96,110)$. The number of cultivated plants that support populations of $F$. oxysporum f. sp. vasinfectum limits options for rotation, and weed hosts reduce the effectiveness of fallowing. Furthermore, long rotations are not economically feasible for most cotton growers.

Because of the ability of the nematode to increase the incidence of wilt $(63,64,98)$, rotations designed to reduce nematode populations may be successful in disease management. Root-knot nematode-resistant soybeans, grain sorghum, and peanuts are good rotation crops for managing soil populations of this nema- tode (55). Although most grasses and legumes used as winter cover crops are susceptible to root-knot nematodes, they are grown during periods of low soil temperatures and thus do not allow reproduction of the nematode. Because many weeds are hosts for the root-knot nematode $(22,24)$, fallowing is not effective unless weeds are controlled.

Tillage has an impact on both fungal and nematode pathogens in the soil $(66,102)$. The influence of tillage on Fusarium wilt of cotton has not been thoroughly researched, but it is expected that tillage will have little effect on $F$. oxysporum f. sp. vasinfectum because of its ability to survive in the soil for extended periods as chlamydospores. It is possible that conservation tillage practices may reduce the dissemination of the pathogen, which may reduce the incidence of disease, but this has not been thoroughly investigated. In Australia, the impact of retaining cotton residues on the surface rather than incorporating them immediately after harvest reduced wilt-induced seedling mortality by $31 \%$ (2). It was hypothesized that the exposure to sunlight and repeated wetting and drying cycles may have affected survival of $F$. oxysporum f. sp. vasinfectum.

Tillage operations impact both biotic and abiotic factors that may affect nematode mortality, but it may also affect the spread of nematode inoculum (66). In Arkansas, the impact of reduced tillage on the disease complex was compared with conventional tillage following a winter fallow or two winter cover crops, hairy vetch and common vetch (20). Incidence of Fusarium wilt was not affected by tillage or winter cover crop. The severity of root-knot nematode damage in a subsequent cotton crop was not affected by winter cover crop, but was higher with reduced tillage. Although wilt was not increased in this study, the increase in the severity of root galling by the nematode associated with reduced tillage could lead to an increase in Fusarium wilt in some situations because of the ability of the root-knot nematode to increase Fusarium wilt $(63,64,98)$.

Soil solarization effectively reduced the survival of $F$. oxysporum f. sp. vasinfectum in the soil and incidence of wilt. The survival of $F$. oxysporum f. sp. vasinfectum buried in the soil was reduced by $97.5,58$, and $0 \%$ with two layers of polyethylene film, a single layer of film, and an uncovered control, respectively (11). The combination of metam-sodium and solarization was more effective in destroying both $F$. oxysporum f. sp. vasinfectum and nematodes than was solarization or metamsodium alone (10). Incidence of Fusarium wilt and populations of $F$. oxysporum $\mathrm{f}$. sp. vasinfectum and the root-knot nematode were reduced for 2 years following solarization (25). Although solarization appears to be effective in controlling wilt, it is often not economically feasible for large- scale cotton production. Also, treated fields are out of production for much of 1 year during the solarization treatment.

Summer flooding successfully reduced the incidence of Fusarium wilt in Australia (2). The ability of producers to flood land and leave it idle for a year is prohibitive, but the practice has merit and may be practical in some instances.

Most management studies have been based on reports from the United States and presumably with race 1 . It is assumed that management with other races will be similar, but the role of other races of $F$. oxysporum $\mathrm{f}$. sp. vasinfectum in relation to most of the management approaches needs to be investigated. For example, isolates of race 4 from California were more virulent on Pima cottons and were not associated with the root-knot nematode (54). These observations will have an impact on rotation strategies and the ability to reduce wilt losses by managing the nematode.

Management of the Fusarium wilt/rootknot nematode complex remains difficult. Resistance is the simplest and most effective management strategy, but until cultivars with higher levels of resistance to both pathogens are available, crop rotation and the application of nematicides are possible alternatives. These methods are usually more effective in managing the root-knot nematode than controlling the wilt pathogen.

\section{Potential for Long-Range Dissemination and Impact}

F. oxysporum f. sp. vasinfectum is transported in seed, plant residue, and soil. Even with the widespread movement of seed, races of the pathogen are somewhat geographically restricted, suggesting that the pathogen either is not easily disseminated by this mechanism or has difficulty in becoming established. However, the distinct distribution of some races may be based on the specific type of cotton grown in an area, thus influencing the movement of plant material or establishment of the pathogen. Recent work in California by Kim et al. (54) suggests there may be greater variability of the pathogen in the United States than previously appreciated. The dissemination of the pathogen in the United States is difficult to determine because the pathogen was widespread when it was first recognized as the casual agent of Fusarium wilt (8). Moreover, symptoms of Fusarium wilt are often associated with nematode damage. Thus, this interaction influences perceptions of the distribution of $F$. oxysporum f. sp. vasinfectum, which may be much greater than realized. In the absence of nematodes, much higher populations of $F$. oxysporum $\mathrm{f}$. sp. vasinfectum were required for the development of symptoms (32).

Dispersal of the pathogen by water is probably important for field-to-field and 
farm-to-farm spread. In Israel, dispersal of the pathogen by water in furrow irrigation systems was much greater $(130 \mathrm{~m})$ than dispersal of the pathogen by movement of soil during cultivation (4 to $8 \mathrm{~m}$ ) (36). However, movement of the pathogen in soil on equipment, vehicles, or field workers is probably important for local spread and possibly over greater areas where cuscotton to the gin and disposal of gin trash also may play a role in pathogen dispersal (45).

Dissemination over long distances is most likely due to the movement of seed. For example, race 1 was probably introduced into Tanzania from the Americas, possibly in cottonseed imported for crushing (28). Infected seed hulls that remained after expressing oil also have the potential tom field operations occur. Movement of

for spread of $F$. oxysporum $\mathrm{f}$. sp. vasinfectum (107). Hillocks and Kibani (41) suggested infested seed used for planting played a large role for the distribution of the pathogen within Tanzania. However, the ability of the pathogen to survive in seed drops precipitously after a few months $(29,57)$. In addition, the nearly universal use of fungicides on seed in some areas, e.g., the United States, for the control of seedborne and soilborne pathogens may reduce the risk of planting seed as a source of $F$. oxysporum f. sp. vasinfectum (1).

Cottonseed is also used as feed in the dairy industry. In recent years, large shipments of methyl bromide-fumigated cottonseed have been exported from Australia into the United States (54). In replicated trials, $F$. oxysporum was never isolated
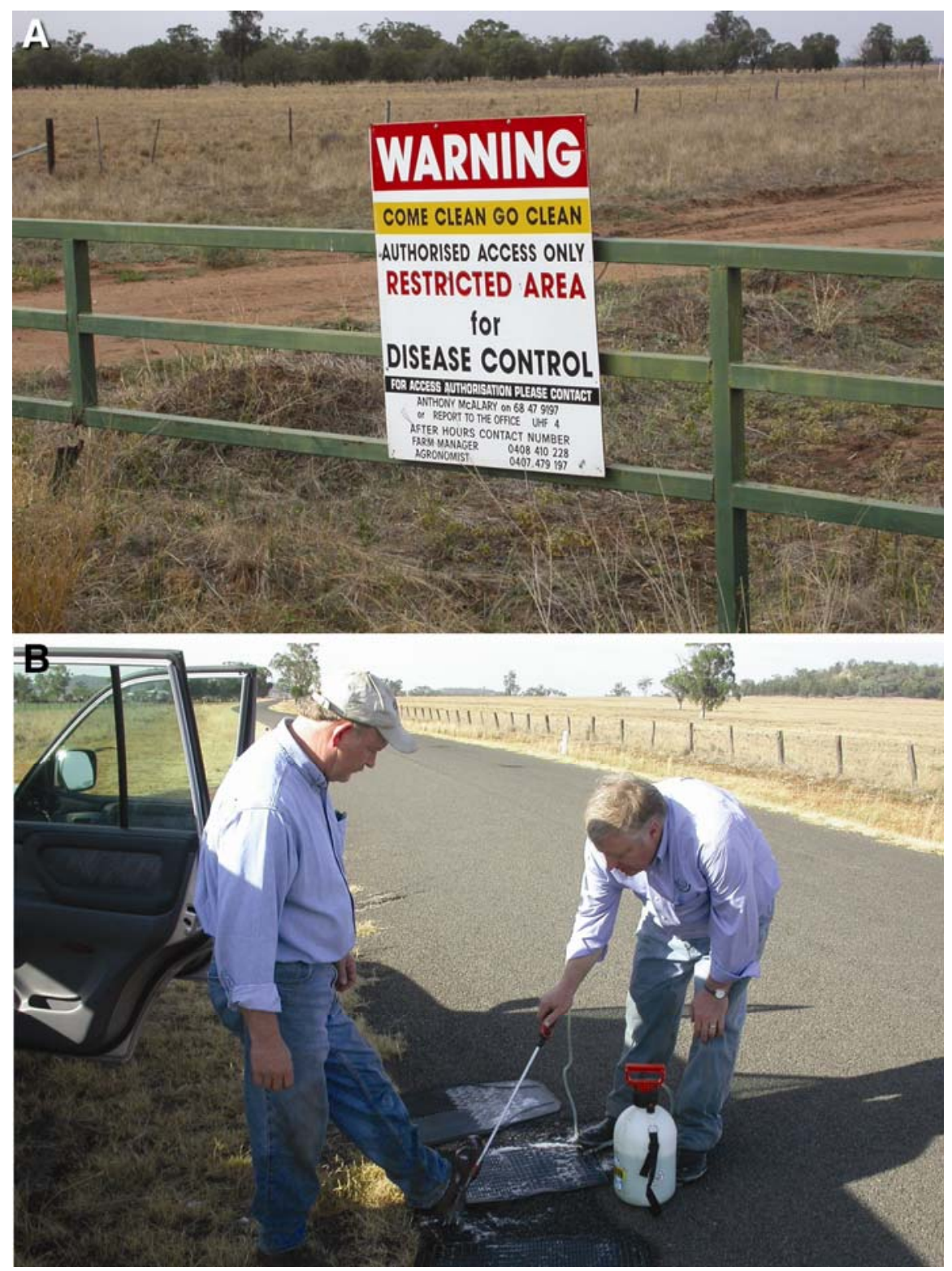

Fig. 7. A, "Come Clean Go Clean" policy implemented in Australia to slow the movement of Fusarium oxysporum f. sp. vasinfectum among fields and cotton production areas. B, Boots, vehicles, and farm equipment are disinfected when leaving a farm where Fusarium wilt of cotton has been identified. from fumigated seed (even from gins in areas of Australia known to have fields heavily infested with the pathogen), but other Fusarium spp. were detected at low levels. When fed to dairy cows, only $2 \%$ of cottonseed remained intact, and isolation of Fusarium spp. was decreased fourfold in intact seed in fresh manure and was never isolated from dried manure (68).

The spread of Fusarium wilt in Australia is probably the best documented example of dissemination of $F$. oxysporum $\mathrm{f}$. sp. vasinfectum. Systematic disease surveys of cotton in Australia have been conducted since the industry was rejuvenated in the 1960s with the construction of a number of reservoirs in New South Wales and Queensland and the relocation of two California cotton growers to Wee Waa, New South Wales (71). Fusarium wilt was first discovered in fields in Darling Downs in 1993 (56), and the distribution of the disease since that time has been closely monitored. Soon after its discovery, the disease was identified in a separate river system some $200 \mathrm{~km}$ southwest of the initial site of detection. Distinct populations, based on DNA fingerprints and VCGs, were identified as the Darling Downs (VCG01111) and Boggabilla (VCG01112) biotypes. The pathogen now has been detected in other production areas in Australia, but other areas have remained free of the pathogen. VCG01111 is the predominant biotype while VCG01112 is confined to a few fields mainly in the Boggabilla area. The movement of the pathogen within and between fields, especially those downstream, has been documented. New infestations have been associated with floods that moved infested soil to new sites or new farms. In addition, the pathogen was apparently introduced into some new areas by the movement of farm equipment or vehicles. Cotton is frequently produced in rotation with wheat, and contract harvest operations often move from north to south in Australia. An extensive educational program and a "Come Clean Go Clean" policy of disinfesting shoes, equipment, and vehicles moving between farms and production areas were instituted soon after the disease was identified (Fig. 7A and B). These efforts played a major role in slowing the dissemination of the pathogen within Australia. Because seed production in Australia was outside of the initial infested areas, seed transmission probably did not play a significant role in movement of the pathogen. The seed industry in Australia has implemented strict voluntary regulations on seed production in relation to farms and areas infested with the pathogen.

Invasive species with mechanisms for widespread dispersal and active secondary cycles are often mentioned as threats to crop production, e.g., the recent introduction of soybean rust pathogen into the United States (84). However, some soil- 
borne pathogens also have great potential as invasive species because of their ability to survive for long periods in the absence of the primary host. F. oxysporum f. sp. vasinfectum, for example, survives longterm both as chlamydospores and on symptomless hosts. In addition, soilborne pathogens can be difficult or impossible to eradicate from the soil environment. Examples of the spread of important new or introduced soilborne pathogens include Phytophthora ramorum in the United States (80) and $F$. oxysporum f. sp. vasinfectum in cotton-growing regions of Australia. The recent documentation of new virulent biotypes of $F$. oxysporum $\mathrm{f}$. sp. vasinfectum in Australia has raised concerns about the introduction of these biotypes into other areas of the world. This concern is warranted because of the extent of damage observed on Australian cotton crops even in the absence of nematodes (2). If introduced into other areas, damage would not be limited to fields with soil textures favorable for nematode survival and damage. In addition, Australian biotypes caused damage over a $\mathrm{pH}$ range of 4 to 8.5 (105), indicating that the fungus could survive in many soil types. Once the pathogen is introduced into a new area, there is little likelihood of eradicating it, and management of the disease is difficult.

\section{Future Research}

Concern over the introduction and dissemination of new biotypes of $F$. $o x$ ysporum f. sp. vasinfectum has greatly increased since the new populations in Australia were characterized. There has been limited research on characterization of populations of the pathogen in the United States. In 1983, Kappelman (50) found that race 2 was more widespread than previously assumed. The recent report of races 3, 4, and 8 in California emphasizes the need for more research on the population structure in the United States (54). This is critically important since race 4 is currently causing considerable damage on Pima cotton in California in the absence of the nematode. To characterize populations of $F$. oxysporum f. sp. vasinfectum, a set of cotton differentials needs to be established by screening a large number of cotton cultivars to a worldwide collection of $F$. oxysporum f. sp. vasinfectum. This also would help establish the breadth of resistance genes in cotton. Furthermore, the conditions for pathogenicity tests (temperature range, light intensity, inoculum concentrations, and assessment criteria) should be standardized. In addition, studies on characterizing populations should include molecular techniques and VCG assays, all of which should be standardized using specific protocols. It is also anticipated that some DNA-based methods will be developed for the detection of the pathogen in seed and soil.
Because resistance in cotton cultivars to F. oxysporum f. sp. vasinfectum offers the promise of sustained and robust control of Fusarium wilt, breeding efforts should continue. Differences in the susceptibility of cotton genotypes to Fusarium wilt have been demonstrated in many active screening programs throughout the world. However, a high level of resistance has not been found to all biotypes of the pathogen. No doubt the incorporation of resistance will need to continue as new strains of the pathogen emerge. The Australian situation is but the latest example of the occurrence of new pathogenic biotypes.

Finally, there is a need to examine the importance of sub-symptomatic parasitism by $F$. oxysporum f. sp. vasinfectum. In many cases, the pathogen colonizes cotton plants without inducing foliar symptoms. Although some vascular discoloration may be present, interacting factors such as plant vigor, climatic conditions, interactions with other soilborne micro-organisms, etc., allow the host to tolerate colonization to some degree. Studies that attempt to quantify yield losses, if any, due to subsymptomatic infections are lacking since appropriate controls are difficult to obtain. Damage by nematodes further confounds the determination of yield losses to Fusarium wilt in many cases.

Fusarium wilt has long been a problem in cotton and will continue to be an important disease. The recent emergence of the disease in Australia from an apparent indigenous population of $F$. oxysporum has raised this disease to one of great research interest and importance.

\section{Literature Cited}

1. Allen, S. J., and Kochman, J. K. 2001. Eliminating seed-borne inoculum of Fusarium oxysporum f. sp. vasinfectum in cotton. Pages 139-140 in: Proc. Beltwide Cotton Conf. National Cotton Council of America, Memphis, TN.

2. Allen, S. J., and Lonergan, P. A. 2000. Control strategies for Fusarium wilt of cotton in Australia. Pages 136-138 in: Proc. Beltwide Cotton Conf. National Cotton Council of America, Memphis, TN.

3. Armstrong, G. M., and Armstrong, J. K. 1948. Nonsusceptible hosts as carriers of wilt Fusaria. Phytopathology 38:808-826.

4. Armstrong, G. M., and Armstrong, J. K. 1960. American, Egyptian, and Indian cottonwilt Fusaria: Their pathogenicity and relationship to other wilt Fusaria. U.S. Dep. Agric. Tech. Bull. 1219.

5. Armstrong, G. M., and Armstrong, J. K. 1978. A new race (race 6) of the cotton-wilt Fusarium from Brazil. Plant Dis. Rep. 62:421-423.

6. Armstrong, J. K., and Armstrong, G. M. 1958. A race of the cotton-wilt Fusarium causing wilt of Yelredo soybean and fluecured tobacco. Plant Dis. Rep. 42:147-151.

7. Assigbetse, K. B., Fernandez, D., Dubois, M. P., and Geiger, J.-P. 1994. Differentiation of Fusarium oxysporum f. sp. vasinfectum races on cotton by random amplified polymorphic DNA (RAPD) analysis. Phytopathology 84:622-626.

8. Atkinson, G. F. 1892. Some diseases of cotton. 3. Frenching. Bull. Ala. Agric. Exp. Stn. 41:19-29.
9. Baird, R., and Carling, D. 1998. Survival of parasitic and saprophytic fungi on intact senescent cotton roots. J. Cotton Sci. 2:27-34.

10. Ben-Yephet, Y., Melero-Vera, J. M., and DeVay, J. E. 1988. Interaction of soil solarization and metham-sodium in the destruction of Verticillium dahliae and Fusarium oxysporum f. sp. vasinfectum. Crop Prot. 7:327-331.

11. Ben-Yephet, Y., Stapleton, J. J., Wakeman, R. J., and DeVay, J. E. 1987. Comparative effects of soil solarization with single and double layers of polyethylene film on survival of Fusarium oxysporum f. sp. vasinfectum. Phytoparasitica 15:181-185.

12. Blasingame, D., and Patel, M. V. 2005. Cotton disease loss estimate committee report Pages 259-262 in: Proc. Beltwide Cotton Conf. National Cotton Council of America, Memphis, TN.

13. Bridge, P. D., Ismail, M. A., and Rutherford, M. A. 1993. An assessment of aesculin hydrolysis, vegetative compatibility and DNA polymorphism as criteria for characterizing pathogenic races within Fusarium oxysporum f. sp. vasinfectum. Plant Pathol. 42:264-269.

14. Burgess, L. W., Liddell, C. M., and Summerell, B. A. 1988. Laboratory Manual for Fusarium Research, 2nd ed. University of Sydney, Australia.

15. Charudattan, R. 1969. Studies on strains of Fusarium vasinfectum Atk. Proc. Indian Acad. Sci. Section B. 70:139-156.

16. Charudattan, R., and Kalyanasudaram, R. 1966. Carrier hosts of $F$. vasinfectum Atk. Phytopathol. Z. 55:239-242.

17. Chen, Q., Ji, X., and Sun, W. 1985. Identification of races of cotton wilt Fusarium in China. Agric. Sci. China 6:1-6.

18. Colyer, P. D., Caldwell, W. D., Vernon, P. R. and Hayes, J. 2002. 2001 National cotton Fusarium wilt report - Louisiana. Unpaginated in: Proc. Beltwide Cotton Conf. National Cotton Council of America, Memphis, TN

19. Colyer, P. D., Kirkpatrick, T. L., Caldwell, W. D., and Vernon, P. R. 1997. Influence of nematicide application on the severity of the root-knot nematode-Fusarium wilt disease complex in cotton. Plant Dis. 81:66-70.

20. Colyer, P. D., Kirkpatrick, T. L., Vernon, P. R., Barham, J. D., and Bateman, R. J. 1994. Incidence of Fusarium wilt under conventional and reduced tillage following different cover crops. Pages 42-50 in: Conservation Technology in Arkansas Agriculture 1994. M. McClelland and T. Keisling, eds. Ark. Agric. Exp. Stn. Res. Ser. 449.

21. Cooper, W. E., and Brodie, B. B. 1963. A comparison of Fusarium-wilt indices of cotton varieties with root-knot and sting nematodes as predisposing agents. Phytopathology 53:1077-1080.

22. Davidson, T. R., and Townshend, J. L. 1967. Some weed hosts of the southern root-knot nematode, Meloidogyne incognita. Nematologica 13:452-458.

23. Davis, R. D., Moore, N. Y., and Kochman, J. K. 1996. Characterisation of a population of Fusarium oxysporum f. sp. vasinfectum causing wilt of cotton in Australia. Aust. J. Agric. Res. 47:1143-1156.

24. Davis, R. F., and Webster, T. M. 2005. Relative host status of selected weeds and crops for Meloidogyne incognita and Rotylenchulus reniformis. J. Cotton Sci. 9:41-46. Online publication.

25. DeVay, J. E., Garber, R. H., Roberts, P. A., Wakeman, R. J., and Jeffers, D. P. 1985. The effect of soil solarization on soil-borne populations of Fusarium oxysporum f. sp. vasinfectum and Meloidogyne incognita in relation to the incidence of Fusarium wilt and yield of cotton plants. Page 36 in: Proc. Beltwide Cotton Conf. National Cotton Council of America, Memphis, TN.

26. DeVay, J. E., Gutierrez, A. P., Pullman, G. S., Wakeman, R. J., Garber, R. H., Jeffers, D. P. Smith, S. N., Goodell, P. B., and Roberts, P. 
A. 1997. Inoculum densities of Fusarium oxysporum f. sp. vasinfectum and Meloidogyne incognita in relation to the development of Fusarium wilt and the phenology of cotton plants (Gossypium hirsutum). Phytopathology 87:341-346.

27. Dishon, I., and Nevo, D. 1970. The appearance of Fusarium wilt in the Pima cotton cultivar. Hassadeh 56:2281-2283.

28. Ebbels, D. L. 1975. Fusarium wilt of cotton: A review, with special reference to Tanzania. Cotton Grower Rev. 52:295-339.

29. Elliott, J. A. 1923. Cotton wilt; a seed borne disease. J. Agric. Res. 23:387-393.

30. Fahmy, T. 1927. The Fusarium disease (wilt) of cotton and its control. Phytopathology 17:749-767.

31. Fernandez, D., Assigbetse, K., Dubois, M.-P., and Geiger, J.-P. 1994. Molecular characterization of races and vegetative compatibility groups in Fusarium oxysporum f. sp. vasinfectum. Appl. Environ. Microbiol. 60:40394046.

32. Garber, R. H., Jorgenson, E. C., Smith, S., and Hyer, A. H. 1979. Interaction of population levels of Fusarium oxysporum f. sp. vasinfectum and Meloidogyne incognita on cotton. J. Nematol. 11:133-137.

33. Garber, R. H., and Paxman, G. A. 1963. Fusarium wilt of cotton in California. Plant Dis. Rep. 47:398-400.

34. Garrett, S. D. 1944. Root Disease Fungi. Chronica Botanica Co., Waltham, MA

35. Garrett, S. D. 1970. Pathogenic root-infecting fungi. Cambridge University Press, London.

36. Grinstein, A., Fishler, G., Katan, J., and Hakohen, D. 1983. Dispersal of the Fusarium wilt pathogen in furrow-irrigated cotton in Israel. Plant Dis. 67:742-743.

37. Grover, R. K., and Singh, G. 1970. Pathology of wilt of okra (Abelmoschus esculentus L. Moench) caused by Fusarium oxysporum f. sp. vasinfectum (Atk.) Snyder \& Hansen, its host range and histopathology. Indian J. Agric. Sci. 40:989-996.

38. Hering, O., Nirenberg, H. I., Koehn, S., and Deml, G. 1999. Characterization of isolates of Fusarium oxysporum Schlecht. f. sp. vasinfectum (Atk.) Snyd. \& Hans., races 1-6, by cellular fatty acid analysis. J. Phytopathol. 147:509-514.

39. Hillocks, R. J. 1983. Infection of cotton seed by Fusarium oxysporum f. sp. vasinfectum in cotton varieties resistant or susceptible to Fusarium wilt. Trop. Agric. (Trinidad) 60:141-143.

40. Hillocks, R. J. 1992. Fusarium wilt. Pages 127-160 in: Cotton Diseases. R. J. Hillocks, ed. C.A.B. International, Wallingford, UK.

41. Hillocks, R. J., and Kibani, T. H. M. 2002. Factors affecting the distribution, incidence and spread of Fusarium wilt of cotton in Tanzania. Expl. Agric. 38:13-27.

42. Holdeman, Q. L., and Graham, T. W. 1954. Effect of sting nematode on expression of Fusarium wilt in cotton. Phytopathology 44:683-685.

43. Hyer, A. H., Jorgenson, E. C., Garber, R. H., and Smith, S. 1979. Resistance to root-knot nematode in control of root-knot nematodeFusarium wilt disease complex in cotton. Crop Sci. 19:898-901.

44. Ibrahim, F. M. 1966. A new race of the cotton-wilt Fusarium in the Sudan Gezira. Emp. Cotton Grow. Rev. 43:296-299.

45. Jeffers, D. P., Smith, S. N., Garber, R. H., and DeVay, J. E. 1984. The potential spread of the cotton Fusarium wilt pathogen in gin trash and planting seed. (Abstr.) Phytopathology 74:1139.

46. Jones, J. E., Newson, L. D., and Finley, E. L. 1959. Effect of reniform nematode on yield, plant characters, and fiber properties of upland cotton. Agron. J. 51:353-356.

47. Jorgenson, E. C., Hyer, A. H., Garber, R. H., and Smith, S. N. 1978. The influence of soil fumigation on the Fusarium root-knot- nematode complex of cotton in California. J. Nematol. 10:228-231.

48. Kappelman, A. J., Jr. 1971. Inheritance of resistance to Fusarium wilt in cotton. Crop Sci. 11:672-674

49. Kappelman, A. J., Jr. 1980. Long-term progress made by cotton breeders in developing Fusarium wilt resistant germplasm. Crop Sci. 20:613-615.

50. Kappelman, A. J., Jr. 1983. Distribution of races of Fusarium oxysporum f. sp. vasinfectum within the United States. Plant Dis. 67:1229-1231.

51. Kappelman, A. J., Jr., and Bird, L. S. 1981. Indirect selection for resistance to the Fusarium wilt-root-knot nematode complex in cotton. Crop Sci. 21:66-68.

52. Katan, T., and Katan, J. 1988. Vegetativecompatibility grouping of Fusarium oxysporum f. sp. vasinfectum from tissue and the rhizosphere of cotton plants. Phytopathology 78:852-855.

53. Katsantonis, D., Hillocks, R. J., and Gowen, S. 2003. Comparative effect of root-knot nematode on severity of Verticillium and Fusarium wilt in cotton. Phytoparasitica 31:154-162.

54. Kim, Y., Hutmacher, R. B., and Davis, R. M. 2005. Characterization of California isolates of Fusarium oxysporum f. sp. vasinfectum. Plant Dis. 89:366-372.

55. Kirkpatrick, T. L., and Sasser, J. N. 1984. Crop rotation and races of Meloidogyne incognita in cotton root-knot management. J. Nematol. 16:323-328.

56. Kochman, J. K. 1995. Fusarium wilt in cotton, A new record in Australia. Autralas. Plant Pathol. 24:74

57. Kochman, J. K., Swan, L. J., O’Neill, W. T., and Bentley, S. 2003. Detection, persistence and control of Fusarium oxysporum f. sp. vasinfectum in cotton seed in Australia. Pages 185-190 in: Proc. Beltwide Cotton Conf. National Cotton Council of America, Memphis, TN

58. Koenning, S. R., Barker, H. R., and Bowman, D. T. 2001. Resistance as a tactic for management of Meloidogyne incognita on cotton in North Carolina. J. Nematol. 33:126-131.

59. Koenning, S. R., Kirkpatrick, T. L., Starr, J. L., Wrather, J. A., Walker, N. R., and Mueller, J. D. 2004. Plant-parasitic nematodes attacking cotton in the United States: Old and emerging production challenges. Plant Dis. 88:100-113.

60. Kulkarni, G. S. 1934. Studies in the wilt disease of cotton in the Bombay Presidency. Indian J. Agric. Sci. 4:976-1045.

61. Kumar, S. U., Kalyanasundaram, R., and Kumar, V. U. 1986. The preparation and use of fluorscent antibody reagent for the detection of Fusarium vasinfectum. Can. J. Bot. 64:1003-1005.

62. Leslie, J. F., Pearson, C. A. S., Nelson, P. E., and Toussoun, T. A. 1990. Fusarium spp. from corn, sorghum, and soybean fields in the central and eastern United States. Phytopathology 80:343-350.

63. Mai, W. F., and Abawi, G. S. 1987. Interactions among root-knot nematodes and Fusarium wilt fungi on host plants. Annu. Rev. Phytopathol. 25:317-338.

64. Martin, W. J., Newson, L. D., and Jones, J. E. 1956. Relationship of nematodes to the development of Fusarium wilt in cotton. Phytopathology 46:285-289.

65. Michell, R. E., and Powell, W. M. 1972. Influence of Pratylenchus brachyurus on the incidence of Fusarium wilt in cotton. Phytopathology 62:336-338.

66. Minton, N. A. 1986. Impact of conservation tillage on nematode populations. J. Nematol. 18:135-140.

67. Minton, N. A., and Minton, E. B. 1966. Effect of root-knot and sting nematodes on expression of Fusarium wilt of cotton in three soils. Phytopathology 56:319-322.
68. Moore, N. Y., O’Neil, W. T., Moss, R., and Blaney, B. 2001. Assessment of the risk of transmission of Fusarium oxysporum $\mathrm{f}$. $\mathrm{sp}$ vasinfectum in cottonseed, through the digestive system of dairy cows. Dep. Primary In dustries, Queensland, Australia, Report, Dec. 2001.

69. Moricca, S., Ragazzi, A., Kasuga, T., and Mitchelson, K. R. 1998. Detection of Fusarium oxysporum $\mathrm{f}$. sp. vasinfectum in cotton tissue by polymerase chain reaction. Plant Pathol. 47:486-494.

70. Neal, D. C. 1954. The reniform nematode and its relationship to the incidence of Fusarium wilt of cotton at Baton Rouge, Louisiana. Phytopathology 44:447-450.

71. Nehl, D. B., Allen, S. J., Mondal, A. H., and Lonergan, P. A. 2004. Black root rot: A pandemic in Australian cotton. Australas. Plan Pathol. 33:87-95.

72. Nelson, P. E. 1981. Life cycle and epidemiology of Fusarium oxysporum. Pages 51-80 in: Fungal Wilt Diseases of Plants. M. E. Mace, A. A. Bell, and C. H. Beckman, eds. Academic Press, New York.

73. Nelson, P. E., Toussoun, T. A., and Marasas, W. F. O. 1983. Fusarium species: An Illustrated Manual for Identification. Pennsylvania State University, University Park

74. Nicholson, P. 2001. Molecular assays as aids in the detection, diagnosis and quantification of Fusarium species in plants. Pages 176-192 in: Fusarium: Paul E. Nelson Memorial Symposium. B. A. Summerell, J. F. Leslie, D. Backhouse, W. L. Bryden, and L. W. Burgess, eds. American Phytopathological Society, St. Paul, MN

75. Nirenberg, H. I., Ibrahim, G., and Michail, S H. 1994. Race identity of three isolates of Fusarium oxysporum Schlect. f. sp. vasinfectum (Atk.) Snyd. \& Hans. from Egypt and the Sudan. Z. Pflanzenkr. Pflanzenschutz 101:594-597.

76. Perry, D. A. 1963. Interaction of root-knot and Fusarium wilt of cotton. Emp. Cotton Growing Rev. 40:41-47.

77. Powell, N. T. 1971. Interactions between nematodes and fungi in disease complexes. Annu. Rev. Phytopathol. 9:253-274.

78. Rajaram, B. 1979. Biochemical association between infection of Hoplolaimus seinhorsti Luc, 1958 and the development of Fusarium oxysporum f. sp. vasinfectum (Atk.) Synder \& Hansen on cotton. Indian Zoologist 3:135-138.

79. Reid, P., Allen, S., Kochman, J., Stiller, W. McNamara, G., Lehane, J., and Constable, G. 2004. Sicot F-1: A variety with increased resistance to Fusarium wilt. Pages 739-740 in: Proc. 12th Australian Cotton Conference. Australian Cotton Growers Res. Assoc., Wee Waa, Australia.

80. Rizzo, D. M., Garbelotto, M., Davidson, J. M., Slaughter, G. W., and Koike, S. T. 2002 Phytophthora ramorum as the cause of extensive mortality of Quercus spp. and Lithocar pus densiflorus in California. Plant Dis. $86: 205-214$

81. Robinson, A. F., Cook, C. G., and Percival, A E. 1999. Resistance to Rotylenchulus reniformis and Meloidogyne incognita race 3 in the major cotton cultivars planted since 1950 . Crop Sci. 39:850-858

82. Rutherford, M. A., Patterson, R. R. M. Bridge, P. D., and Brayford, D. 1993. Coumarin utilization patterns of pathogenic races of Fusarium oxysporum causing vascular wilt of cotton. J. Phytopathol. 138:209-216.

83. Sangalang, A. E., Burgess, L. W., Backhouse, D., Duff, J., and Wurst, M. 1995. Mycogeography of Fusarium species in soils from tropical, arid, and mediterranean regions of Australia. Mycol. Res. 99:523-528.

84. Schneider, R. W., Hollier, C. A., Whitam, H K., Palm, M. E., McKemy, J. M., Hernandez, J. R., Levy, L., and DeVries-Paterson, R. 2005. First report of soybean rust caused by Phakopsora pachyrhizi in the continental 
United States. Plant Dis. 89:774.

85. Shepherd, R. L. 1974. Transgressive segregation for root-knot nematode resistance in cotton. Crop Sci. 14:872-875.

86. Shepherd, R. L. 1982. Genetic resistance and its residual effects for control of the root-knot nematode-Fusarium wilt complex in cotton. Crop Sci. 22:1151-1155.

87. Shepherd, R. L. 1986. Cotton resistance to the root knot-Fusarium wilt complex. II. Relation to root-knot resistance and its implications on breeding for resistance. Crop Sci. 26:233-237.

88. Shepherd, R. L., and Kappelman, A. J. 1986. Cotton resistance to the root knot-Fusarium wilt complex. I. Relation to Fusarium wilt resistance and its implications on breeding for resistance. Crop Sci. 26:228-232.

89. Skovgaard, K., Nirenberg, H. I., O’Donnell, K., and Rosendahl, S. 2001. Evolution of Fusarium oxysporum f. sp. vasinfectum races inferred from multigene genealogies. Phytopathology 91:1231-1237.

90. Smith, A. L. 1941. The reaction of cotton varieties to Fusarium wilt and root-knot nematode. Phytopathology 31:1099-1107.

91. Smith, A. L. 1948. Control of cotton wilt and nematodes with a soil fumigant. Phytopathology 38:943-947.

92. Smith, A. L. 1953. Fusarium and nematodes on cotton. Pages 292-298 in: Yearbook of Agriculture. A. Stefferud, ed. USDA, U.S. Gov. Print. Office, Washington, DC

93. Smith, A. L., and Dick, J. B. 1960. Inheritance of resistance to Fusarium wilt in upland and Sea Island cottons as complicated by nematodes under field conditions. Phytopathology 50:44-48.

94. Smith, S. N., DeVay, J. E., Hsieh, W.-H., and Lee, H.-J. 2001. Soil-borne populations of Fusarium oxysporum f. sp. vasinfectum, a cotton wilt fungus in California fields. Mycologia 93:737-743

95. Smith, S. N., Ebbels, D. L., Garber, R. H., and Kappelman, A. J., Jr. 1981. Fusarium wilt of cotton. Pages 29-38 in: Fusarium: Diseases, Biology, and Taxonomy. P. E. Nelson, T. A. Toussoun, and R. J. Cook, eds. Pennsylvania State University, University Park.

96. Smith, S. N., and Snyder, W. C. 1975. Persistence of Fusarium oxysporum f. sp. vasinfectum in fields in the absence of cotton. Phytopathology 65:190-196.

97. Snow, J. P., and Sanders, D. E. 1979. Role of abscised cotton flowers, bolls, and squares in production of inoculum by boll-rotting $\mathrm{Fusa}$ rium spp. Plant Dis. Rep. 63:288-289.

98. Starr, J. L., Jeger, M. J., Martyn, R. D., and Schilling, K. 1989. Effects of Meloidogyne incognita and Fusarium oxysporum $\mathrm{f}$. sp. vasinfectum on plant mortality and yield of cotton. Phytopathology 79:640-646.

99. Starr, J. L., and Smith, C. W. 1993. Root-knot nematodes and Fusarium-wilt resistance to both pathogens. Pages 178-179 in: Proc. Beltwide Cotton Conf. National Cotton Council of America, Memphis, TN.

100. Starr, J. L., and Veech, J. A. 1986. Susceptibility to root-knot nematodes in cotton lines resistant to the Fusarium wilt/root-knot complex. Crop Sci. 26:543-546.

101. Subramanian, C. V. 1950. Soil conditions and wilt diseases in plants with special reference to Fusarium vasinfectum on cotton. Proc. Indian Acad. Sci., Section B. 31:67-102.

102. Sumner, D. R., Doupnik, B., Jr., and Boosalis, M. G. 1981. Effects of reduced tillage and multiple cropping on plant diseases. Annu. Rev. Phytopathol. 19:167-187.

103. Taylor, A. L., Barker, H. D., and Kime, P. H. 1940. Further observations on the nematodefusarium-wilt experiments at Lumberton, North Carolina. (Abstr.) Phytopathology 30:710.

104. Wang, B., Dale, M. L., and Kochman, J. K. 1999. Studies on a pathogenicity assay for screening cotton germplasms for resistance to Fusarium oxysporum f. sp. vasinfectum in the

glasshouse. Aust. J. Exp. Agric. 39:967-974.

105. Wang, B., Dale, M. L., Kochman, J. K., and Obst, N. R. 1999. Effects of plant residue, soil characteristics, cotton cultivars and other crops on fusarium wilt of cotton in Australia. Aust. J. Exp. Agric. 39:203-209.

106. Webster, J. M. 1985. Interaction of Meloidogyne with fungi on crop plants. Pages 183192 in: An advanced treatise on Meloidogyne. Vol. I. Biology and Control. J. N. Sasser and C. C. Carter, eds. North Carolina State Univ. Graphics, Raleigh, NC

107. Wickens, G. M. 1964. Fusarium wilt of cotton. Seed husk a potential means of dissemination. Cotton Growing Review 41:23-26.

108. Williams, K. R., Kirkpatrick, T., Bond, B.

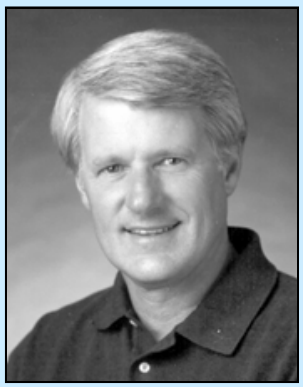

R. M. Davis

Dr. Davis is a professor of plant pathology and Specialist in Cooperative Extension in the Department of Plant Pathology at the University of California, Davis. He received a B.A. in biology from California State University, Long Beach, and a Ph.D. from the University of California, Riverside. His research focuses on the epidemiology and control of diseases of vegetables and field crops, especially those caused by fungal and bacterial pathogens.

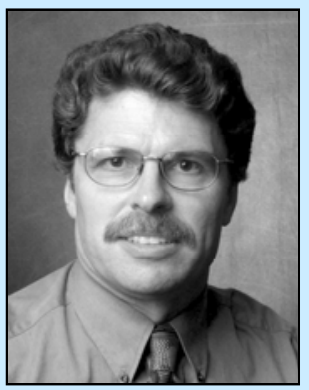

\section{S. Rothrock}

Dr. Rothrock is a professor in the Department of Plant Pathology at the University of Arkansas. He received a B.S. degree in botany from lowa State University and M.S. and Ph.D. degrees in plant pathology from the University of Illinois, Urbana-Champaign. His research examines the ecology of soilborne plant pathogens and their control through chemical, cultural, and alternative strategies, and focuses on developing sustainable cropping systems for cotton and other field crops. and Jaggers, J. 2002. Root-knot nematode (Meloidogyne incognita) control and carryover effects of Telone II (1, 3 dichloropropene) in cotton in Ashley County, Arkansas. Unpaginated cd-rom in: Proc. Beltwide Cotton Conf. National Cotton Council of America, Memphis, TN

109. Windels, C. E. 1993. Fusarium. Pages 115 128 in: Methods for Research on Soilborne Phytopathogenic Fungi. L. L. Singleton, J. D. Mihail, and C. M. Rush, eds. American Phytopathological Society, St. Paul, MN.

110. Wood, C. M., and Ebbels, D. L. 1972. Host range and survival of Fusarium oxysporum $\mathrm{f}$. sp. vasinfectum in North-western Tanzania. Cotton Grower Rev. 49:79-82.

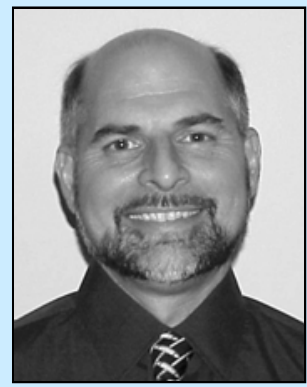

P. D. Colyer

Dr. Colyer is a professor of plant pathology at the Louisiana State University Agricultural Center's Red River Research Station. Dr. Colyer received his B.S. in biology from Edinboro State College, Edinboro, PA, in 1978, and his Ph.D. in plant pathology from the University of Massachusetts in Amherst in 1983. He is responsible for research on the epidemiology and management of economic diseases of cotton, wheat, and soybean. The focus of his research involves the epidemiology and management of seedling diseases and the Fusarium wilt/root-knot nematode disease complex in cotton.

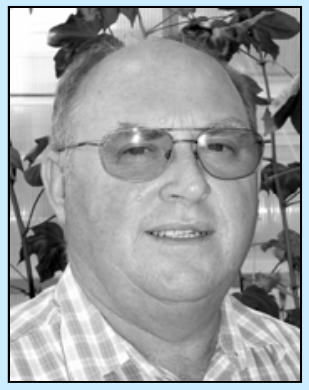

\section{J. K. Kochman}

Dr. Kochman is a Principal Plant Pathologist with the Queensland Department of Primary Industries and Fisheries, based at Toowoomba in southern Queensland, Australia. He received a Ph.D. from the University of New England, Armidale, New South Wales, Australia in 1974. His research examines epidemiology, host genetic resistance, and other control strategies for a range of diseases of field crops. He is a founding member of the Australasian Plant Pathology Society. 